\title{
SEMINARIO INTERDISCIPLINAR "TRANSMISSIONS: MONASTERIES AS SITES OF CULTURAL TRANSFERS", (Centro de Estudios Ibero-Americanos, 25 y 26 de septiembre de 2017, Praga)
}

El seminario interdisciplinar "Transmissions": Monasteries as Sites of Cultural Transfers tuvo lugar en las instalaciones del Centro de Estudios Ibero-Americanos (en adelante sólo SIAS) entre los días 25 y 26 de septiembre de 2017. El evento internacional se celebró en colaboración de SIAS (en aquel entonces Mgr. Monika Brenišínová), el Instituto de Historia de Artes de Academia de Ciencias de República checa (en adelante solo ÚDU AV ČR, Mgr. Lenka Panušková, Ph.D.) y el Instituto Francés para la Investigación en Ciencias Sociales y Humanidades con sede en Praga (en adelante solo CEFRES, Mgr. et Mgr. Katalin Pataki).

El seminario, conducido en inglés, fue solemnemente abierto el primer día del evento por las directoras y/o personas destacadas de la triada de las instituciones mencionadas: Markéta Křížová de SIAS, Tat'ána Petrasová del Instituto de Artes Históricas y Clara Royer del CEFRES.

Durante el primer día tuvieron lugar tres secciones sucesivas. La primera sección Interpretation and Context fue presidida por Veronika Čapská del Departamento de Antropología de la Facultad de Humanidades de Universidad Carolina (en adelante solo FHS UK). En ella se presentaron dos ponencias (desafortunadamente la tercera ponencia de la prof. Jana Králova del Instituto de Traductología de la Facultad de Artes de la Universidad Carolina no se pudo presentar por motivos de salud): la primera fue presentada por Martin Lešák del Departamento de Historia del Arte de la Universidad de Masaryk de Brno de y llevó el títu1o "Monasteries on the Horizon: The Sacral Landscape Through the Senses of Medieval Pilgrims"; siendo la otra -intitulada "Other Time: Construction of Temporality in Benedictine Monasteries"- presentada por Jan Tesárek y Barbora Spalová.

El evento siguió después de la pausa para el almuerzo con el segundo bloque nombrado Monastic Networks: Technology and Society presidido por Jan Zdichynec del Departmento de Historia checa de FHS UK (Por razones familiares no pudo participar Szekér Barnabás con su "Whose Instructions? - Educational Orders, Administration, and Rules of Higher Schools in the 18th Century Kingdom of Hungary") siendo su primera ponencia "The Monasteries as Mediators of Medical Knowledge - Camaldolese Pharmacies of the Hungarian Kingdom and Austria" expuesta por Katalin Pataki, una de las coordinadoras del evento.

El tercer panel Devotion and Vocation: The Transition of Ideas fue dirigido por Markéta Křížová del SIAS. La primera ponencia, cuyo autor fue Antonio Bueno del Departamento de Traductología de la Universidad de Valladolid, denominada "To Whom May Read This. The Prologue of Linguistic Works and Translations of the Dominicans as the Main Ideas for Reflection on Translation Theory" se dio por Skype. La segunda charla fue presentada por Monika Brenišínová, una de las autoras del seminario, bajo el título "Mexican Monasteries and Processions. The Transmission of Ideas, Space and Time". La sección fue cerrada por Marcin F. Rdzak, estudiante posgradual en historia y estudios archivísticos, de la Universidad Pontífica de San Pablo II en Kraków con su contribución "Books of Enrollment to the Fraternity of the Scapular (1911-1946) from the Convent of Carmelite Fathers in Lwow. The Transition of Devotional Patterns".

El primer día del evento lo concluyó la conferencia con el tema de "Transfer, Translation and Transmission of Knowledge in Monastic Networks - Research Directions and Approaches in the Study of Medieval and Early Modern Patterns" presentada por el ponente principal del seminario József Laszlovszky, renombrado arqueólogo y especialista en el campo de estudios medievales, del Departamento de Estudios Medievales de la Universidad de Europa Central de Budapest. 
Al día siguiente, el seminario empezó con la sección Arts and Architecture: Transferring the Forms presidida por Lenka Panušková del ÚDU AV ČR. Esta parte fue introducida por la contribución "El Escorial jako duchovní model českých a moravských klášterů ve světle současné interpretace (Hradisko, Kuks, Plasy)" [El escorial as a Spiritual Model of Czech and Moravian Monasteries in the Light of the Contemporary Interpretation (Hradisko, Kuks, Plasy)] fue presentada en checo por el historiador del arte Pavel Štěpánek de la Universidad Palacký de Olomouc siendo este bloque cerrado por Jana Povolná, estudiante del Instituto de la Historia del Arte Cristiano de la Facultad de Teología Católica de Universidad Carolina, con su contribución "Sázava Monastery: St Procop, Scriptorium and the Church".

A la última sesión Writing Monastery presidida por Kateřina Bobková del ÚDU AV ČR contribuyeron Renata Modráková de la Biblioteca Nacional de La República checa con su charla "Benedictine St. George's Monastery at the Prague Castle as a Crossroad of Medieval Cultural Trend and Ideas", Jan Kremer del AV ČR con la ponencia "Religious Identity and Order Discipline Early Thirteenth-Century Bohemian Premonstratensians" y Kristian Bertović "Glagolitic monks Monastic Continuity and Glagolitic Script in the Medieval Croatia and the Istrian Peninsula".

El seminario terminó con la presentación de los proyectos dedicados a la problemática monástica. Se presentaron los siguientes proyectos: Klášterní stezky [Senderos monásticos] del Departamento de Historia y Didáctica Histórica de la Facultad de Pedagogía de la Universidad Carolina (véase http://www.klasterni-stezky.cz); luego Kateřina Horníčková presentó el proyecto Visions of Community un proyecto de VISCOM de la Universidad de Viena (véase https://viscom.ac.at /home); además fue presentado el proyecto Religious Orders of Early Hungary (véase http://szerzetes.hypotheses.org); y finalmente Jan Zdichynec del Departmento de Historia checa de FHS UK presentó el proyecto Zdroje, formy a funkce monastické historiografie raného novověku v českých zemích [Sources, Forms, and Functions of the Monastic Historiography in Early Modern Ages in the Czech Lands]. Para concluir el congreso dijeron varias palabras las coordinadoras del evento Lenka Panušková (IAH CAS), Katalin Pataki (CEFRES) y Monika Brenišínová (SIAS FF UK).

Los resúmenes de todas las ponencias se pueden ver en la página web disponible en checo e inglés https://transmissions.ff.cuni.cz. Las ponencias serán publicadas en una monografía colectiva llevando el título del seminario mismo en la casa editorial Archeopress en Oxford en 2019.

El evento fue clausurado con una excursión guiada por PhDr. Kateřina Kubínová, Ph.D. del ÚDU AV ČR del Monasterios de Eslavos de Emaús, uno de los más prestigiosos conventos de la República checa. Dicho monasterio fue fundado por Carlos IV en 1347 y, pronto, se convirtió en centro de erudición, arte y literatura eslavas. En su interior se conservan restos de pinturas góticas murales que fueron presentadas por Kateřina $\mathrm{Ku}$ bínová, la autora de una monografía sobre el programa iconográfico del lugar.

por Monika Brenišínová (Praga) (Escrito en español por la autora) 